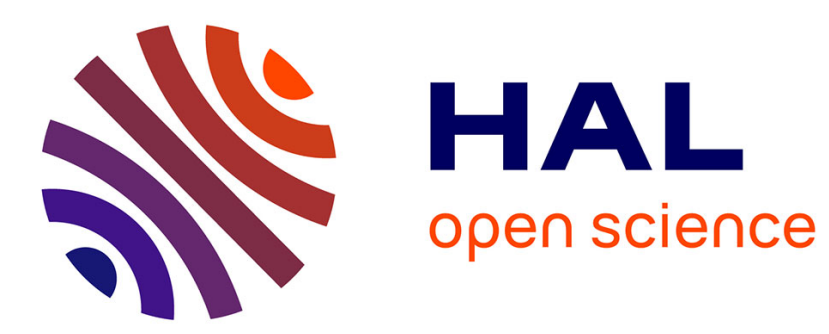

\title{
The Responsiveness of Food Retail Supply Chains: A Norwegian Case Study
}

Heidi C. Dreyer, Natalia Swahn, Kasper Kiil, Jan Ola Strandhagen, Anita Romsdal

\section{- To cite this version:}

Heidi C. Dreyer, Natalia Swahn, Kasper Kiil, Jan Ola Strandhagen, Anita Romsdal. The Responsiveness of Food Retail Supply Chains: A Norwegian Case Study. IFIP International Conference on Advances in Production Management Systems (APMS), Sep 2015, Tokyo, Japan. pp.152-160, 10.1007/978-3-319-22756-6_19. hal-01417454

\section{HAL Id: hal-01417454 \\ https://hal.science/hal-01417454}

Submitted on 15 Dec 2016

HAL is a multi-disciplinary open access archive for the deposit and dissemination of scientific research documents, whether they are published or not. The documents may come from teaching and research institutions in France or abroad, or from public or private research centers.
L'archive ouverte pluridisciplinaire HAL, est destinée au dépôt et à la diffusion de documents scientifiques de niveau recherche, publiés ou non, émanant des établissements d'enseignement et de recherche français ou étrangers, des laboratoires publics ou privés.

\section{(c)(1)}

Distributed under a Creative Commons Attribution| 4.0 International License 


\title{
THE RESPONSIVENESS OF FOOD RETAIL SUPPLY CHAINS: A NORWEGIAN CASE STUDY
}

\author{
Heidi C. Dreyer, Natalia Swahn, Kasper Kiil, Ola Strandhagen, Anita Romsdal
}

The Norwegian University of Technology and Science, Department of Production and Quality Engineering, 7491, Trondheim, Norway

E-mail: heidi.c.dreyer@ntnu.no, Tel: +4798291146

\begin{abstract}
This paper describes a case study which highlights responsiveness in a Norwegian retail supply chain. The dynamics in the conventional food market is increasing which is seen in online and multichannel shopping concepts, a wide range of campaigns and promotions, and demographic changes. While the conventional food supply chains are designed to handle large product volumes efficiently, this might impact on the responsiveness. This study explores the relation between the responsiveness and demand pattern in Norwegian food retail supply chains, and identifies key principles for the associated planning and control models
\end{abstract}

Keywords: supply chain responsiveness, food retail supply chain, case study

\section{$1 \quad$ Introduction}

In Norway the conventional food supply chain is serving a dynamic marketplace with a broad range of different consumer segments claiming high a service level and low prices. Consumers look for convenience and alternative ways to buy food, such as online shopping and home deliveries. The complexity of the dynamic market is amplified by the characteristics of food products, e.g. short shelf life, temperature and weather sensitivity, and strong seasonal features (Ivert et al., 2014).

The conventional food supply chain has responded to the market dynamics by developing highly industrial processes. Over the past decades the main supply chain strategy has been to restructure production facilities, warehouses, distribution centres and stores to handle large product volumes efficiently, becoming less responsive as a result (Hübner et al., 2013). However, the need of the supply chains to adapt to rapidly changing market environment is increasing (Thatte et al., 2013). Hübner, et al., 2013 point out the misalignment of supply and demand in the retail supply chain and the need for planning and control models in order to coordinate the wide range of decisions.

This study explores the relation between the responsiveness and demand pattern in Norwegian food retail supply chains, and identifies key principles for the associated planning and control models. 


\section{Supply chain responsiveness and flexibility}

The organization's ability to adjust to market dynamics is one of its core capabilities, and the means to achieve competitive advantage (Bernardes and Hanna, 2009; Lee et al., 2004). The key concepts in this respect are responsiveness and flexibility (Reichhart and Holweg, 2007). Responsiveness tends to be linked to the changes of behaviour required by the system's external environment. It also includes some time or effort dimension, such as speed of response (Thatte et al., 2013). In this study, responsiveness is defined as a system performance capability to timely change behavior in response to external stimuli. Flexibility, in turn, is defined as an operating characteristic and a system's ability to change status within an existing configuration of pre-established parameters enabling the system to be responsive.

This distinction between internal flexibility and requirements for responsiveness is reflected in Reichhart and Holweg's (2007) conceptual framework where the external factors which require the system to be responsive, and the internal factors, which enable the system's responsiveness, are identified. This perspective of responsiveness presents a comprehensive overview of other relevant literature on the subject, and their work has also been recognized in more recent literature (Bernardes and Hanna, 2009). Therefore, it has been operationalized into tangible measures (the study's analytical framework) by supporting literature (Table 1).

The analytical framework specifies the definition of the external and internal factors together with operational measures allowing evaluation of the required responsiveness. Demand uncertainty is related to changes in mix and volume. Demand variability is related to uncertainty, yet is different since large swings in known demand will still require responsiveness. External product variety can directly increase the need for mix responsiveness, potentially increasing demand forecast error. Lead time compression increases the need for responsiveness as less time is available to respond to customer orders. Internal factors that enable responsiveness can be separated into operational factors and supply chain integration. Demand anticipation and the accurate forecast increases ability to respond to customer requirements. Manufacturing flexibility can reduce production lead time and change-over times for products. Inventory can both increase and decrease the responsiveness of supply chains. It is linked to customer order decoupling point (CODP). Product architecture/ postponement determines where CODP is placed, and thus how responsiveness can be achieved. Information integration can reduce demand uncertainty and variability by reducing demand amplification and eliminating delays due to slow information flow. Coordination and resource sharing reduces demand uncertainty and variability by removing delays and unnecessary activities. Organisational integration has a major impact on trust thus affecting a variety of interaction between supply chain members. Spatial integration and logistics lead to the reduction of transport lead times and strengthens process coordination and organisational integration by moving supply chain partners physically closer together or implementing infrastructural improvements. 
Table 1. Elaboration of external and internal factors (Ivert et al., 2014; Romsdal, 2014; Chopra and Meindl, 2013; Thatte et al., 2013; van Donk et al., 2008; Reichhart and Holweg, 2007; Min et al., 2005).

\begin{tabular}{|c|c|c|}
\hline & Definition & Operational measure \\
\hline \multicolumn{3}{|c|}{ External requirements } \\
\hline Demand uncertainty & $\begin{array}{l}\text { Stems from volume/mix } \\
\text { changes in customer demand }\end{array}$ & $\begin{array}{l}\text { Stability in volume; stability in } \\
\text { mix; degree of campaigns }\end{array}$ \\
\hline Demand variability & Large swings in demand & Stability in volume; seasonality \\
\hline $\begin{array}{l}\text { External product } \\
\text { variety }\end{array}$ & $\begin{array}{l}\text { The number of SKUs available to } \\
\text { at any point in time }\end{array}$ & $\begin{array}{l}\text { Number of SKUs; service level; } \\
\text { change in product portfolio/NPI }\end{array}$ \\
\hline $\begin{array}{l}\text { Lead time } \\
\text { compression }\end{array}$ & $\begin{array}{l}\text { Required or expected response } \\
\text { time to fulfil a customer order }\end{array}$ & Shelf life; delivery time \\
\hline \multicolumn{3}{|c|}{ Internal determinants Operational factors } \\
\hline Demand anticipation & $\begin{array}{l}\text { How accurately products are } \\
\text { forecasted }\end{array}$ & Forecast error; safety stock \\
\hline $\begin{array}{l}\text { Manufacturing } \\
\text { flexibility }\end{array}$ & $\begin{array}{l}\text { The degree to which operations } \\
\text { is capable of changing without } \\
\text { compromising throughput time }\end{array}$ & $\begin{array}{l}\text { Ability to handle changes in: } \\
\text { volume, mix., deliveries, and } \\
\text { product portfolio/NPI }\end{array}$ \\
\hline Inventory & $\begin{array}{l}\text { Inventories as buffer against } \\
\text { demand uncertainty }\end{array}$ & Inventory allocations and levels \\
\hline $\begin{array}{l}\text { Product architecture } \\
\text { / postponement }\end{array}$ & $\begin{array}{l}\text { The postponement of differentia- } \\
\text { tion }\end{array}$ & $\begin{array}{l}\text { Order complexity; CODP; cus- } \\
\text { tomer base complexity }\end{array}$ \\
\hline \multicolumn{3}{|c|}{ Internal determinants Supply chain integration } \\
\hline $\begin{array}{l}\text { Information } \\
\text { integration }\end{array}$ & $\begin{array}{l}\text { Transparency and information } \\
\text { availability within the supply } \\
\text { chain }\end{array}$ & $\begin{array}{l}\text { Use of information exchange } \\
\text { between supply chain partners }\end{array}$ \\
\hline $\begin{array}{l}\text { Coordination and } \\
\text { resource sharing }\end{array}$ & $\begin{array}{l}\text { How processes are coordinated } \\
\text { across firm boundaries }\end{array}$ & $\begin{array}{l}\text { Joint problem solving; speed of } \\
\text { communication }\end{array}$ \\
\hline $\begin{array}{l}\text { Organizational } \\
\text { integration }\end{array}$ & $\begin{array}{l}\text { Integration of information, } \\
\text { monetary and material flow }\end{array}$ & $\begin{array}{l}\text { Type of relationship between } \\
\text { partners/ level of trust }\end{array}$ \\
\hline $\begin{array}{l}\text { Spatial integration } \\
\text { and logistics }\end{array}$ & $\begin{array}{l}\text { Logistical proximity which } \\
\text { reduces lead-times }\end{array}$ & $\begin{array}{l}\text { Infrastructure; physical distribu- } \\
\text { tion }\end{array}$ \\
\hline
\end{tabular}

\section{$3 \quad$ Methodology}

The purpose of the study is to explore the relation between the responsiveness of the food retail supply chains in Norway and the demand pattern. Since it is limited to the retailer perspective, an explorative single case study has been chosen. The strength of the case study methodology is the ability to study in-depth elements and relations in real-life situations which often can be highly complex (Yin, 2009), and, by this to explore new phenomena (Eisenhart, 1989). The food retail supply chain of Coop Handel has been selected because its supply chain is comparable to the other retailers. 
Coop Handel is one of three big Norwegian food retailers; NorgesGruppen (40\%), Coop Handel (22\%), and Rema (24\%) (Nielsen, 2015). The supply chain structure of the retailers is quite similar with a strong wholesaler unit (a combination of centralised and decentralised warehouses) and a trade unit (different stores and concepts).

Data for the case study has been collected and triangulated through interviews, point-of-sales data, orders requirements, insight to internal terms and conditions, and workshops.

\section{Coop Handel}

Coop is a consumer cooperative, owned by over 100 Norwegian cooperatives. The organization consists of a wholesaler and retailer unit, which together supply 796 stores. The stores are profiled under 5 different concepts, and are supplied either from the central warehouse, from one or several of the regional warehouses or a combination of centrally and regional storage. In the following sections the data from the case study is described and structured according to the framework developed in section 2.

Table 2: The external factors in the Coop supply chain

\begin{tabular}{|c|c|}
\hline & Supply Chain \\
\hline $\begin{array}{l}\text { Demand } \\
\text { uncertainty }\end{array}$ & $\begin{array}{l}\text { Stores: Changes in mix and volumes due to campaigns and loyalty card offer- } \\
\text { ings, weather and seasonality. Differs between the five concept stores, store } \\
\text { localization and size. Fig. } 2 \text { illustrates the uncertainty for one of the five con- } \\
\text { cepts. Wholesaler: Changes in mix and volumes due to seasonality, campaigns. } \\
\text { About } 10 \% \text { of the products are at any time on campaigns. Supplier: Changes in } \\
\text { mix and volume. Supply uncertainty due to raw material quality. }\end{array}$ \\
\hline $\begin{array}{l}\text { Demand } \\
\text { variability }\end{array}$ & $\begin{array}{l}\text { Stores: Demand variability is observed especially in regards to the stores' de- } \\
\text { mand at the warehouse and the warehouse's demand towards the suppliers as } \\
\text { seen in Fig. 1. Wholesaler: Variability in purchased volume and mix. Supplier: } \\
\text { Variability in volume and mix. }\end{array}$ \\
\hline $\begin{array}{l}\text { Product } \\
\text { variety }\end{array}$ & $\begin{array}{l}\text { Stores: Varies. SKU: Coop OBS! }-9.800 \text {; Coop Mega - 10.900; Coop Extra - } \\
\text { 7.800; Coop Prix - } 6.800 \text {; Coop Market - 6.800. The service level varies be- } \\
\text { tween the SKU's with } 97 \% \text { on average. Wholesaler: About } 38.000 \text { SKU. Prod- } \\
\text { uct are launched } 3 \text { times/year. Supplier: Varies between some few up to } 100 \text {. }\end{array}$ \\
\hline $\begin{array}{l}\text { Lead time } \\
\text { compression }\end{array}$ & $\begin{array}{l}\text { Stores: } 2 \text { days lead time. Daily delivery to big and central stores. Min. } 3 \text { deliver- } \\
\text { ies/week to other stores. Min. } 1 / 3 \text { of the remaining shelf life left when delivered } \\
\text { to the store. Wholesaler: } 1 \text { day delivery time. Min. } 2 / 3 \text { of the remaining shelf } \\
\text { life left when delivered to the wholesaler. Supplier: } 1 \text { day delivery time. }\end{array}$ \\
\hline
\end{tabular}

Table 2 shows the uncertainty and variability of demand and the causes (seasonality, market activities, product range and product launches). In Figure 1 and 2, variation in all the three parts of the supply chain is seen. First, there is a variation between store concepts, time periods and the product mix and volume. Second, table 2 demonstrates the role of supply uncertainty relative to the quality of raw materials. Third, 
table 2 show the lead time compression and the shelf life restrictions impact delivery frequency, though the impact depends on the localization and the size of the store.
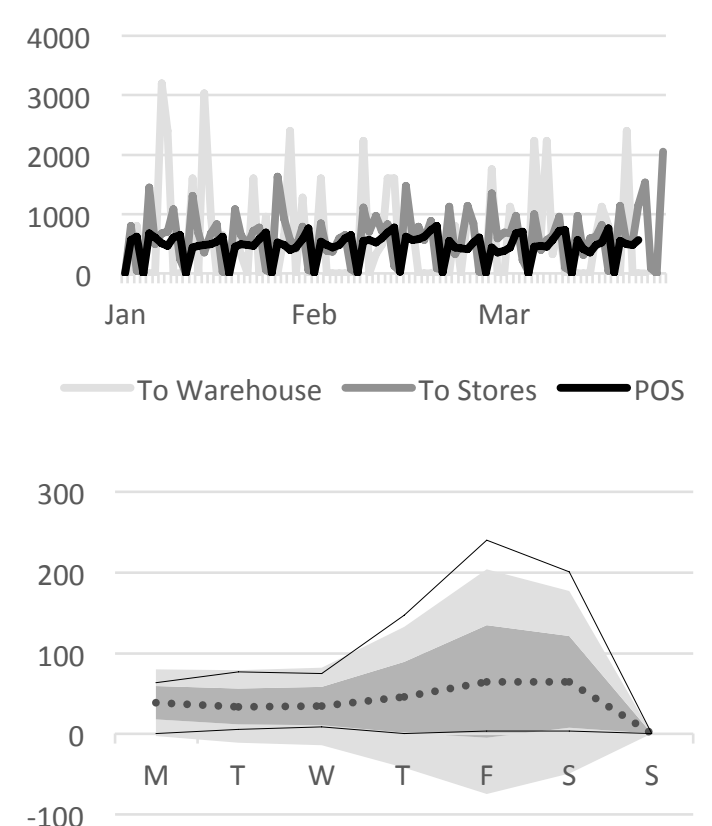

Figure 1: 'POS' reflects what the demand to the consumers, 'to stores' reflects what have been delivered from the warehouse to the stores, and 'to warehouse' reflects what have been delivered from the suppliers to the warehouse. There is a clear sign of varying demand, especially to the stores and to the warehouse.

Figure 2: The dotted line represents an average demand at one store concept for three months. The dark gray area is \pm 1 stdv., light gray is \pm 2 stdv., the thin black lines are min. and max. values. Demand uncertainty, especially towards weekends, also observed at other store concepts.

Table 3 Internal factors in the Coop supply chain

\section{Supply Chain}

Store: The average shelf level is between A (not under $40 \%$ of sale), B (not under $30 \%$ of sale) or $\mathrm{C}$ (not under $10-20 \%$ of sale) products. The goal is an

Demand anticiaverage of $97 \%$ service level. Wholesaler: The average stock level is 3

pation days (max 5-8), but differs with regard to product, season and market. The stock level is used as a buffer for demand variability and uncertainty. Forecast error is not used systematically to adjust parameters. Supplier: Use forecasts and historical sales to estimate demand.

Store: Product variety is decided by the store concept. Low mix flexibility. Wholesaler: Purchase to stock. Volume flexibility in picking and packing and mix flexibility at the central warehouse because fully automated mix

Manufacturing palletizing, but mix flexibility is reduced since orders with full pallets or flexibility loads are discounted. Small stores can order a mix crate but achieve no discounts. Fixed delivery schedules (time and date). Supplier: Volume flexibility because of make-to-stock production. Limited mix flexibility caused by set up cost and time.

Store: Automated replenishment of dry, frozen and some chilled products. 


\begin{tabular}{ll}
\hline & min. stock level/push stock. Wholesaler: Driven by scale and volume prin- \\
& ciples. Fixed stock level and stock order-up-to replenishment principles. \\
& Yearly volume and discount contracts with suppliers and weekly call-offs. \\
& Supplier: Stock of raw materials and finished goods. \\
\hline & Store: The order size is driven by volume discounts and varies by store \\
concept, localization and size. Min. delivery frequency is $2-3$ times/week. & Product shelf life varies from a few days to several weeks/months. Whole- \\
Product archi- & saler: Product mix flexibility because of the broad product range. CODP: \\
tecture / post- & central warehouse, regional warehouse or at the supplier. Decided by type \\
ponement & of product and order volume. Supplier: Pick and packs to order. \\
\hline
\end{tabular}

An observation from Table 3 is that volume flexibility in the supply chain is determined by the production and stocking principles (capacity utilization and service level requirements) and the push supply, which is supported by economic incentives (pallet and full load discount). However, the table also shows that when and how products are delivered is decided by the inventory structure (location, CODP and stock level), the fixed transport schedule and the full load requirements which impact flexibility. The broad product range and the number of SKU have a positive impact on mix flexibility. At the same time, ordering principles (AVS, store planogram, transport and delivery frequency) regulate what and when a store is buying. Figures 1 and 2 show the gap between the consumer demand and store replenishment procedures.

Table 4 Supply chain integration in the Coop supply chain

\begin{tabular}{|c|c|}
\hline $\begin{array}{l}\text { Information } \\
\text { integration }\end{array}$ & $\begin{array}{l}\text { The wholesaler and stores shares POS data and stock level information } \\
\text { as input to the automatic replenishment system. Campaign information } \\
\text { is shared with the stores } 2 \text { weeks in advance. Some suppliers receive } \\
\text { forecasts } 6-8 \text { weeks in advance. Most of the orders are automatically } \\
\text { exchanged; portal solution. }\end{array}$ \\
\hline $\begin{array}{l}\text { Coordination and } \\
\text { resource sharing }\end{array}$ & $\begin{array}{l}\text { Transport to stores and from F\&V suppliers, organized by the wholesal- } \\
\text { er. Vendor management inventory is implemented for selected suppliers. } \\
\text { Collaboration between the suppliers of F\&V. }\end{array}$ \\
\hline $\begin{array}{l}\text { Organizational } \\
\text { integration }\end{array}$ & $\begin{array}{l}\text { A transport hub coordinates inbound and outbound transport. The } \\
\text { wholesaler distributes the majority of the products from suppliers. }\end{array}$ \\
\hline $\begin{array}{l}\text { Spatial integration } \\
\text { and logistics }\end{array}$ & $\begin{array}{l}\text { Inventory infrastructure: central and regional warehouses. The transport } \\
\text { network: 2-3 freight forwarders and a fixed transport schedule. Auto- } \\
\text { matic warehouse operations (pick by voice), and fully automated mix } \\
\text { pallet packaging at the central warehouse. The replenishment system: } \\
\text { modules of advanced forecasting and business intelligence. Orders from } \\
\text { stores are transmitted through a portal. }\end{array}$ \\
\hline
\end{tabular}

Table 4 shows that there is collaborative fundament for sharing information and for integrating processes in the supply chain, which positively impact the flexibility (transport hub, supplier organization). However, the table also shows a potential for sharing information that can improve production and transport planning. It is evident that transport, inventory, replenishment, planning and control and information and 
communication technology activities are integrated in some parts of the supply chain (wholesaler, freight forwarder and store).

\section{Discussion}

The analysis of Coop in the previous sub-section shows the relation between the supply chain responsiveness and the demand variability. The demand variability (Figure 1) in the food supply chain, which is a similar observation found in other studies such as Ivert et al. 2014 and Romsdal 2014. However, this study also shows how it varies in the different parts of the chain, the variability between the store concepts and time periods. Even though measuring the level of demand variability is outside the scope of the paper, some research literature (Thatte et al., 2013 and Olhager, 2013) supports our assumption that the variability will become more evident. For the food supply chain, this means that managers should be prepared for handling uncertainty, variability and lead time compression, caused especially by variations in the product shelf life and by broadness of the product range.

The current strategy for dealing with the demand variability is to use inventory and stock levels as a buffer. Products are produced and stored in high volumes and at several locations in the supply chain, which additionally allows the retailers to source, collect and distribute efficiently and achieve product availability. Yearly contracts and discounts determine the total volumes sourced from suppliers and by weekly call-offs based by economic quantities and batch sizes principles impact on the supply chain flexibility (transport schedule, delivery terms and conditions, store planogram). The transport schedule is fixed and set to optimize such criteria as volume, cost, distance, opportunity for return shipment and full pallets. Altogether, these practices impact the order structure. Since there is a discrepancy between the consumer demand pattern and how the store is replenished, and because of the short shelf life of some products, there are reasons for questioning whether the existing strategy is sustainable for achieving overall supply chain responsiveness. To be more responsive and aligned we suggest that the planning and control models should be developed along the following dimensions:

- Integrated planning between production, inventory and replenishment according to consumer demand pattern

- Advanced models for forecasting and demand scenario simulation

- Control principles for dynamic order management

- Methods for reducing batch size, optimal order quantity and load units

- Differentiated supply chains: by store concept, store size and region

- Information sharing between all actors in the supply chain

\section{Conclusion}

This study analyses the responsiveness in the food retail supply chain based on a theoretical framework of responsiveness and a case study of a Norwegian retailer. The 
findings show range of market dynamics and how they are met by a volume, inventory and efficiency strategy. The study also shows that product flow in the supply chain is very much driven be fixed rules and principles designed in order to be efficient and to gain scale benefits which impact on the mix flexibility. Since the shelf life is restricted for many of these products we propose that the strategy should be changed and aligned according to the selling pattern in the store. Since this study is limited to a few products we recommend that future studies include a broader product range.

\section{$7 \quad$ References}

1. Bernardes, E. S. \& Hanna, M. D. (2009). A theoretical review of flexibility, agility and responsiveness in the operations management literature: Toward a conceptual definition of customer responsiveness. International Journal of Operations and Production Management, 29, 30-53.

2. Chopra, S. \& Meindl, P. (2013). Supply chain management: strategy, planning, and operation, Boston, Pearson.

3. Eisenhardt, K. M. (1989), Building theories from case study research, Academy of Management Review, Vol. 14, 4, 532-550.

4. Hübner, A. H. Kuhn, H. and Sternbeck, M. G. (2013). Demand and supply chain planning in grocery retail: an operations planning framework. International Journal of Retail \& Distribution Management, Vol. 41, No. 7, 512-530.

5. Ivert, L. K., Fredriksson, A., Johansson, M. I., Dukovska-Popovska, I., Damgaard, C. M., Kaipia, R., Tuomikangas, N., Dreyer, H. C. \& Chabada, L. (2014). Sales and operations planning: responding to the needs of industrial food producers. Production Planning and Control.

6. Lee, H. L., Padmanabhan, S., Whang, H. L. \& Padmanabhan, H. L. (2004). Information distortion in a supply chain: The bullwhip effect. Management Science, 50, 1875-1886.

7. Min, S., Roath, A. S., Daugherty, P. J., Genchev, S. E., Chen, H., Arndt, A. D. \& Glenn Richey, R. (2005). Supply chain collaboration: what's happening? The International Journal of Logistics Management, 16, 237-256.

8. Nielsen (2015). Daglivarerapporten 2015.

9. Olhager, J. (2013). Evolution of operations planning and control: From production to supply chains. International Journal of Production Research, 51, 6836-6843.

10. Reichhart, A. \& Holweg, M. (2007). Creating the customer-responsive supply chain: A reconciliation of concepts. International Journal of Operations and Production Management, 27, 1144-1172.

11. Romsdal, A. (2014). Differentiated production planning and control in food supply chains. 2014:16, Norwegian University of Science and Technology, Faculty of Engineering Science and Technology, Department of Production and Quality Engineering.

12. Thatte, A. A., Rao, S. S. \& Ragu-Nathan, S. S. (2013). Impact of SCM practices of a firm on supply chain responsiveness and competitive advantage of a firm. Journal of Applied Business Research, 29, 499-530.

13. Van Donk, D. P., Van Der Vaart, T. \& Akkerman, R. (2008). Opportunities and realities of supply chain integration: The case of food manufacturers. British Food Journal, 110, 218 235.

14. Yin, R. K. (2009). Case study research: Design and Methods. $4^{\text {th }}$ ed. Thousand Oaks, CA: Sage Publications 